\title{
A Comparative Study of Melissa officinalis Leaves and Stems Ethanolic Extracts in terms of Antioxidant, Cytotoxic, and Antiproliferative Potential
}

\author{
Elena-Alina Moacă $\mathbb{D}^{\mathbb{D}},{ }^{1}$ Claudia Farcaş, ${ }^{1}$ Alexandra Ghiţu, ${ }^{2}$ \\ Dorina Coricovac $\mathbb{D}^{1},{ }^{1}$ Ramona Popovici, ${ }^{3}$ \\ Nela-Loredana Cărăba-Meiță, ${ }^{4}$ Florina Ardelean, ${ }^{1}$ \\ Diana Simona Antal, ${ }^{1}$ Cristina Dehelean (D), ${ }^{1}$ and Ştefana Avram ${ }^{1}$ \\ 1 "Victor Babes" University of Medicine and Pharmacy Timisoara, Faculty of Pharmacy, \\ Eftimie Murgu Square No. 2, RO-300041, Romania \\ ${ }^{2}$ University of Medicine and Pharmacy Targu Mures, Gheorghe Marinescu Street No. 38, RO-540139, Romania \\ 3 "Victor Babes" University of Medicine and Pharmacy Timisoara, Faculty of Dentistry, \\ Eftimie Murgu Square No. 2, RO-300041, Romania \\ ${ }^{4}$ University of Craiova, Faculty of Economics and Business Administration, Alexandru Ioan Cuza Street No. 13, RO-200764, Romania
}

Correspondence should be addressed to Dorina Coricovac; dorinacoricovac@umft.ro

Received 7 December 2017; Revised 14 February 2018; Accepted 5 March 2018; Published 16 May 2018

Academic Editor: Isabel Andújar

Copyright ( $) 2018$ Elena-Alina Moacă et al. This is an open access article distributed under the Creative Commons Attribution License, which permits unrestricted use, distribution, and reproduction in any medium, provided the original work is properly cited.

Melissa officinalis L. has attracted an increased interest in recent years due to its multiple pharmacological effects. This study aimed to compare two M. officinalis ethanolic extracts, obtained from leaves and stems, with regard to their antioxidant activity, total phenolic content, and cytotoxic effects. M. officinalis ethanolic extracts showed a very good antioxidant activity in the DPPH test, correlated with the content in total phenols: higher in the case of $M$. officinalis from leaves extract (32.76 mg GAE/g) and lower for M. officinalis from stems extract ( $8.4 \mathrm{mg} \mathrm{GAE} / \mathrm{g})$. The lemon balm extracts exerted a cytotoxic effect on breast cancer cells (MDAMB-231) even at low concentrations $(100 \mu \mathrm{g} / \mathrm{mL})$, whereas, in the case of healthy HaCat cells, M. officinalis leaves extract only displayed cytotoxicity at much higher concentrations $(500$ and $1000 \mu \mathrm{g} / \mathrm{mL})$ and $M$. officinalis stems extracts were highly cytotoxic (starting at $100 \mu \mathrm{g} / \mathrm{mL}$ ). In addition, the extracts exerted inhibitory effects on cell migration and proliferation. These results provide information that confirms the high potential of $M$. officinalis as a source of chemopreventive agents. Moreover, these data can be considered a solid background for further in vivo studies involving mice bearing breast tumors.

\section{Introduction}

Melissa officinalis is a perennial herb, member of the Lamiaceae family, known under multiple names, such as bee balm, lemon balm, honey balm, melissa, and garden balm. The use of $M$. officinalis as remedy in traditional medicine dates from many years and several inquiries have been conducted to identify its healing properties [1-8]. M. officinalis has an average height of $30-125 \mathrm{~cm}$ and displays ovate, dark-green leaves and white flowers which bloom in the summer $[9,10]$.
M. officinalis has a large use in traditional medicine, food industry, and aromatherapy, due to its fresh smell and its medicinal properties including hypoglycemic, hepatoprotective, antimicrobial, antidepressant, hypnotic, and sedative $[1,11-14]$. In addition, there are studies that pointed out the cytotoxic effect of lemon balm extract on breast cancer [13] and colon carcinoma [15]. Chemical composition of lemon balm is diverse and includes phenolic acids, tannins, flavonoids, terpenes (triterpenes, monoterpenes, and sesquiterpenes), and volatile compounds. The main active 
ingredients comprise volatile compounds: neral, geranial, citronellal, and geraniol, phenolic compounds: luteolin, caffeic acid, hesperidin, naringin, coumarinic acid, and rosmarinic acid, and triterpenes: oleanolic and ursolic acid [10].

Not only does lemon balm have an impressive background from traditional medicine, but, according to the latest studies, it is effective in cardiovascular disease, by decreasing the values of total lipid concentration, improving HDL (high density lipoprotein) values, and lowering the hepatic synthesis of cholesterol [13].

Lemon balm exerts, as well, an antioxidant effect [16] and is involved in the pituitary gland function by improving the hormonal levels of TSH (thyroid-stimulating hormone), T3 (triiodothyronine), and T4 (thyroxine) [13]. Some studies showed that the extract of $M$. officinalis has antiinflammatory and antinociceptive effect by interacting with muscarinic and nicotinic receptors. Due to the volatile compounds, $M$. officinalis can be used in gastric diseases, by helping the digestion and calming the spasms of the abdominal muscle [1].

Lin and coworkers [17] have studied the composition and the antioxidant and antiproliferative effect of $M$. officinalis extracts. Their studies provided information regarding the composition of the extract of lemon balm and the fact that hot air drying technique is less effective than freeze drying technique because of the losses of phytochemical substances. The authors showed that both types of extracts: freeze dried and hot air dried, displayed antiproliferative activities on the studied cells (HepG2, KB-epidermal carcinoma of the mouth, and TSGH 9201-gastric adenocarcinoma), in a concentration-dependent manner, and regarding the antioxidant effect, the freeze dried extract had higher activity than the hot air extract.

Encalada and coworkers [18] proved the existence of a direct correlation between the phenolic content of $M$. officinalis, the antioxidant effect, and the antiproliferative effect. In addition, it was thought that the content of rosmarinic acid is responsible for the cytotoxic effect in colon human cancer cell lines tested. Based on these data, it was considered that the vegetal extract of $M$. officinalis could represent a good medical strategy in human colon cancer, alongside the cytotoxic drugs.

Most studies are focused on the leaves of the lemon balm, which are the plant product included in pharmacopoeias and which contain a high number of secretory glands. However, more recently, stems and whole aerial parts were as well considered for research, in order to increase the valorization of all herbal material including less common indications [19, 20]. In this idea, our study performs a comparative evaluation of leaves and stems extracts. It undertakes the assessment of the antioxidant activities, the total phenolic contents, and the cytotoxic and the antiproliferative effects of $M$. officinalis extracts obtained from both types of plant organs.

\section{Experimental Part}

\subsection{Materials}

2.1.1. Chemicals and Reagents. The reagents used for obtaining the extracts: ethanol $96 \%$ (v/v), distilled water, 2,2-diphenyl-1-picrylhydrazyl (DPPH) (Batch No: \# STBF5255V), and gallic acid, were purchased from Chemical Company SA, Iasi, Romania, and Sigma Aldrich (Germany), respectively. The ascorbic acid was acquired from Lach-Ner Company (Czech Republic) and the Folin-Ciocalteu reagent from Scharlau (Spain). The chemicals used for cell culture: Dulbecco's modified Eagle Medium (DMEM) high glucose, trypsin/EDTA solution, phosphate saline buffer (PBS), penicillin/streptomycin solution, fetal bovine serum (FBS), Trypan blue, and Alamar blue solutions, were supplied by Sigma Aldrich (Germany) and Thermo Fisher Scientific (USA).

2.1.2. Cell Lines. The cell lines used in the present study: breast adenocarcinoma cells (MDA-MB-231) and human immortalized keratinocytes (HaCat), were acquired from ATCC (American Type Culture Collection) as frozen vials.

2.1.3. Plant Material. Plant samples, Melissa officinalis leaves and stems, were collected from the Botanical garden of "Victor Babes" University of Medicine and Pharmacy Timisoara and identified by the Department of Pharmaceutical Botany. Voucher no. 125/20016 was kept in the mentioned department. After collection, the samples were dried at room temperature and stored in proper conditions.

\subsection{Methods}

2.2.1. Melissa officinalis Ethanolic Extracts Preparation. The two ethanolic extracts were obtained according to the method of Kamdem et al. [21], slightly modified. The ethanolic extracts of $M$. officinalis leaves and stems were obtained as follows: $1 \mathrm{~g}$ of dried and crushed leaves was mixed with $20 \mathrm{~mL}$ ethanol $70 \%$ and sonicated for 30 minutes at room temperature (amplitude $A=50 \%$ and cycle $C=0.5$ ). After sonication the sample was filtered, yielding supernatant $S_{1}$. The plant residue was mixed again with $20 \mathrm{~mL}$ ethanol $70 \%$, and the sonication procedure was repeated at the same parameters and in the same conditions, obtaining supernatant $S_{2}$. The procedure was repeated three more times, and the supernatants $S_{1}-S_{5}$ were reunited, yielding the $M$. officinalis stock solution obtained from leaves. The ethanolic extract of the $M$. officinalis stems was obtained by the same procedure, with the difference that the process was repeated only four times yielding $M$. officinalis stock solution obtained from stems. Thus, two types of ethanolic extracts were prepared from leaves (stock concentration: $10 \mathrm{mg} / \mathrm{mL}$ ) and stems (stock concentration: $12.5 \mathrm{mg} / \mathrm{mL}$ ) of M. officinalis, the schematic protocol being pictured in Figure 1.

2.2.2. Antioxidant Activity Assay. The antioxidant activity of M. officinalis extracts was determined by DPPH- $(2,2-$ diphenyl-1-picrylhydrazyl-) free radical scavenging assay. $\mathrm{DPPH}$-free radical scavenging capacity of the extracts was evaluated according to the method of Manzocco et al. [22]. Briefly, an amount of $0.5 \mathrm{~mL}$ of each extract was added to $2 \mathrm{~mL}$ solvent (ethanol $70 \%, \mathrm{v} / \mathrm{v}$ ) and to $0.5 \mathrm{~mL}$ ethanol solution of DPPH radical $1 \mathrm{mM}$. The absorbance of each sample $\left(A_{\text {sample }}\right)$, including the absorbance of DPPH and 


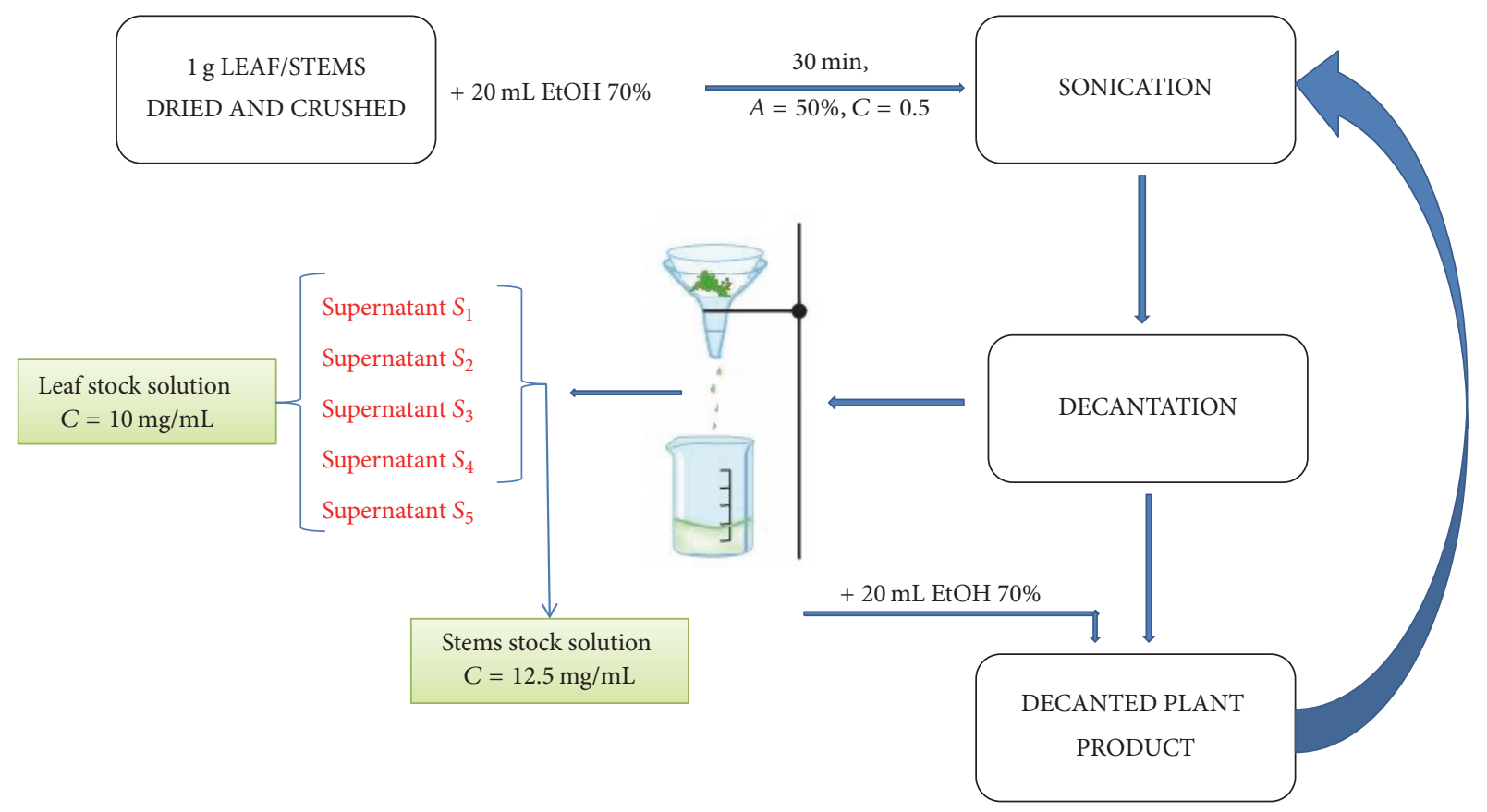

FIGURE 1: Schematic protocol of M. officinalis ethanolic extracts preparation.

ascorbic acid, was measured for 20 minutes continuously, from 5 to 5 seconds, with a T70 UV/VIS Spectrophotometer (PG Instruments Ltd.) at $516 \mathrm{~nm}$. This mode of analysis allows us to determine the reaction speed by which the DPPH is consumed by the antioxidants present in the sample.

The percent of antioxidant activity (\% AOA) of the samples was calculated with the following formula:

$$
\% \mathrm{AOA}=\left[100-\left(\frac{A_{\text {sample }}}{A_{\mathrm{DPPH}}}\right) \times 100\right],
$$

where

AOA is antioxidant activity;

$A_{\text {sample }}$ is absorbance of the sample;

$A_{\mathrm{DPPH}}$ is absorbance of DPPH.

The antioxidant activities of the lemon balm extracts were compared to that of ascorbic acid $(0.1 \mathrm{mg} / \mathrm{mL}$ in ethanol $96 \%$ v/v) used as control.

2.2.3. Determination of Total Phenolic Content (TPC). The total phenolic content (TPC) of the lemon balm extract was estimated by the Folin-Ciocalteu method [23] using gallic acid $(0.1-1 \mathrm{mg} / \mathrm{mL})$ as a standard. This method is based on electron transfer reactions between Folin-Ciocalteu reagent and phenolic compounds, when a blue colored complex that can be quantified spectrophotometrically is formed [23, 24].

In brief, Folin-Ciocalteu reagent (diluted 1:10;2.5 mL) was mixed with plant extract $(0.5 \mathrm{~mL})$ and $\mathrm{Na}_{2} \mathrm{CO}_{3} 7.5 \%$ $(2 \mathrm{~mL})$. The mixture was incubated for 2 hours in the dark at room temperature. Subsequently, absorbance was measured at $750 \mathrm{~nm}$, using a T70 UV/VIS Spectrophotometer (PG Instruments Ltd.). The total phenolic content was expressed as gallic acid equivalents (mg of GAE/g sample). Calibration range of gallic acid was from 0.1 to $1 \mathrm{mg} / \mathrm{mL}$.

2.2.4. Cell Culture. Cells were cultured in Dulbecco's Modified Eagle's Medium (DMEM) high glucose ( $4.5 \mathrm{~g} / \mathrm{L})$ supplemented with $10 \%$ fetal bovine serum (FBS) and $1 \%$ Penicillin/Streptomycin mixture. The cells were maintained in standard conditions, in a humidified atmosphere at $37^{\circ} \mathrm{C}$ and $5 \% \mathrm{CO}_{2}$ in a Steri-Cycle il60 incubator (Thermo Fisher Scientific, USA). Both cell lines were grown in $75 \mathrm{~cm}^{2}$ culture flasks and were routinely passaged every 2-3 days, by treatment with trypsin-EDTA $0.25 \%$, after attaining $80-85 \%$ confluence. Cell counting was performed with Countess ${ }^{\mathrm{TM}}$ II Automated Cell Counter, in Trypan blue presence. All in vitro studies were performed under sterile conditions by using a Biological Safety Cabinet, MSC Advantage 12 model (Thermo Fisher Scientific, USA).

2.2.5. Cell Viability Assay: Alamar Blue. The cytotoxic activity of both $M$. officinalis ethanolic extracts was evaluated on the two cell lines (HaCat and MDA-MB-231) by using Alamar blue $(\mathrm{AB})$ viability test. The $\mathrm{AB}$ assay is based on a colorimetric reaction in which resazurin (dark blue compound) is converted by mitochondrial reductase of viable cells to resorufin (a pink compound with an intense fluorescence).

Briefly, $1 \times 10^{4}$ cells/well were seeded onto a 96-well plate. After $24 \mathrm{~h}$ incubation time, cell media was removed and the attached cells were stimulated with five different concentrations of $M$. officinalis extracts (20, 100, 250, 500, and $1000 \mu \mathrm{g} / \mathrm{mL}$ ) for $24 \mathrm{~h}$. Control cells were stimulated with the same amount of ethanol $70 \%$, as the amount of extract stock solutions added. In order to determine cells viability, the absorbance was measured spectrophotometrically at $570 \mathrm{~nm}$ 
and $600 \mathrm{~nm}$ using a microplate reader $\left(\mathrm{xMark}^{\mathrm{TM}}\right.$ Microplate, Biorad). Wells containing medium without cells were used as negative controls and the results were calculated according to a previous published formula $[25,26]$.

\subsubsection{Antimigratory Potential: Wound Healing Assay Method.} For the determination of a possible inhibitory effect of $M$. officinalis extracts on migration and invasion of both cell lines (MDA-MB-231 and HaCat), the scratch assay test was applied. It is a well-known, practical, and easy method to express cell to cell interactions. The principle of this technique consists of drawing a scratch on the middle of the well, by using a small sterile pipette tip $(10 \mu \mathrm{l})$ and supervising the gap filling by taking pictures at different time points $(0,3$, and $24 \mathrm{~h})$.

A number of $2 \times 10^{5}$ cells/well were seeded onto 12 well culture plates until a $90 \%$ confluence was reached. After that, the gaps/scratches were drawn in each well using a sterile pipette tip. The detached cells were removed by gently washing the plate with PBS. After this step, cells were stimulated with both $M$. officinalis extracts using three different concentrations: 20,100 , and $250 \mu \mathrm{g} / \mathrm{mL}$, and as control the same amount of alcohol as the volume of stock solutions used for preparation of the $M$. officinalis extracts samples was added. Photos were taken at 0,3 , and $24 \mathrm{~h}$ with the Olympus IX73 inverted microscope and the cellSense Dimension software was used to analyze the dimension of the gap.

2.2.7. Statistical Analysis. The statistical programs and software programs applied in the present study were GraphPad Prism 5 and Origin 8 (Origin Lab-Data analysis and Graphing Software). The results were expressed as the mean \pm standard deviation. One-way ANOVA analysis was applied to determine the statistical differences followed by Tukey posttest $\left({ }^{*} p<0.05 ;{ }^{* *} p<0.01 ;{ }^{* * *} p<0.001\right)$.

\section{Results and Discussion}

3.1. Antioxidant Activity Assay. The antioxidant activity (AOA) of the $M$. officinalis stock solution $\left(C_{\text {stock }}=\right.$ $10 \mathrm{mg} / \mathrm{mL})$ obtained from leaves and its five dilutions $\left(C_{1}=\right.$ $5 \mathrm{mg} / \mathrm{mL} ; C_{2}=3 \mathrm{mg} / \mathrm{mL} ; C_{3}=1.5 \mathrm{mg} / \mathrm{mL} ; C_{4}=0.9 \mathrm{mg} / \mathrm{mL}$; $C_{5}=0.5 \mathrm{mg} / \mathrm{mL}$ ) were recorded in a time-dependent manner over 1200 seconds and presented in comparison with ascorbic acid AOA, which was considered the positive control (Figure 2).

The stock solution of $M$. officinalis leaves showed a high antioxidant activity. The ethanolic extract reacted very quickly with DPPH radical, scavenging the substrate in the first 100 seconds. The antioxidant compounds present in the ethanolic extract of $5 \mathrm{mg} / \mathrm{mL}\left(C_{1}\right)$ consumed the DPPH radical in 400 seconds, whereupon the absorbance of the sample slightly decreased, leading to an increased AOA in comparison to that of the stock solution, being very similar to the AOA of ascorbic acid.

Regarding the subsequent dilutions $C_{2}=3 \mathrm{mg} / \mathrm{mL}$ to $C_{5}=0.5 \mathrm{mg} / \mathrm{mL}$, the compounds from the samples reacted with DPPH throughout the recording time of the analysis; all investigated solutions proved to have an antioxidant activity.

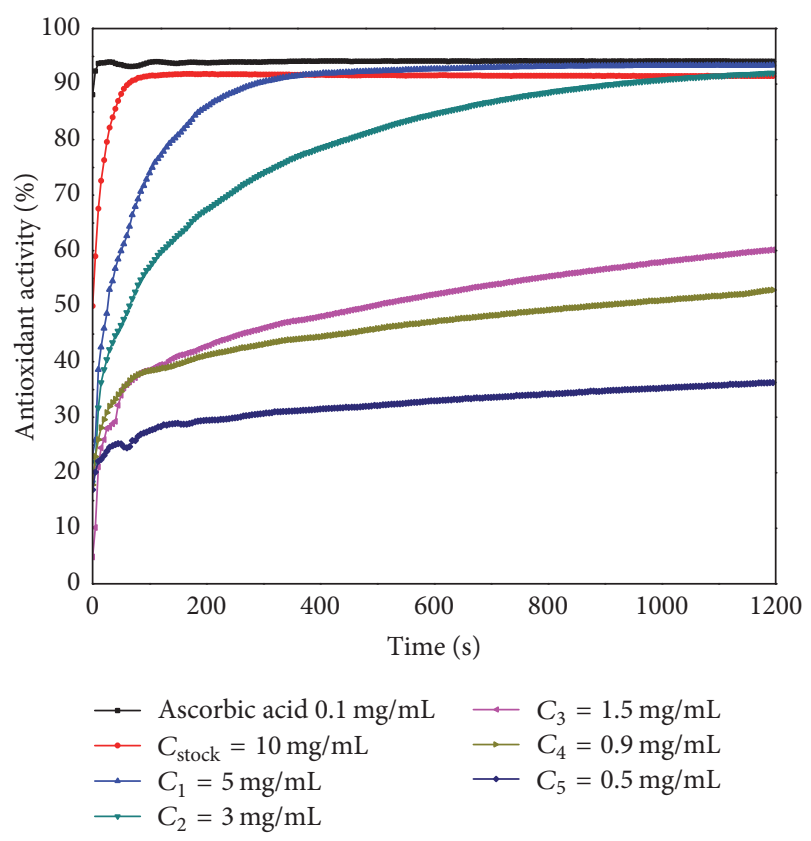

Figure 2: The time-dependent antioxidant activity of the Melissa officinalis leaves ethanolic extract.

The equilibrium was not reached even after 1200 seconds (20 minutes). The AOA of the ethanolic extract of $3 \mathrm{mg} / \mathrm{mL}$ $\left(C_{2}\right)$ attained similar values with the stock solution $\left(C_{\text {stock }}=\right.$ $10 \mathrm{mg} / \mathrm{mL}$ ) extract after 1100 seconds. At the initial moment the AOA values were much lower than the ones recorded at the final moment, after 20 minutes of analysis. Based on these results, it can be concluded that the antioxidant activity of the samples was concentration-dependent. These data are in accordance with the literature $[27,28]$.

The AOA for the ethanolic extract obtained from $M$. officinalis stems was also determined: stock solution $\left(C_{\text {stock }}=\right.$ $12.5 \mathrm{mg} / \mathrm{mL}$ ) and other five dilutions: $C_{1}=6 \mathrm{mg} / \mathrm{mL}, C_{2}=$ $4 \mathrm{mg} / \mathrm{mL}, C_{3}=2 \mathrm{mg} / \mathrm{mL}, C_{4}=1 \mathrm{mg} / \mathrm{mL}$, and $C_{5}=$ $0.6 \mathrm{mg} / \mathrm{mL}$ (Figure 3). The values recorded in time were compared with the AOA of the ascorbic acid.

The highest AOA (attained after 1200 seconds) was displayed by the stock solution, the value being slightly higher than the value recorded for ascorbic acid, although the reaction was much slower than that for ascorbic acid. The components of the $M$. officinalis stems extract used up the DPPH radical after approximately 300 seconds, followed by reaching the reaction equilibrium.

Regarding the dilutions of the stock solution, their kinetic was similar to the one of $M$. officinalis leaves solutions, and equilibrium was not reached even after 20 minutes. Moreover, the first two diluted samples $\left(C_{1}=6 \mathrm{mg} / \mathrm{mL}\right.$ and $C_{2}=$ $4 \mathrm{mg} / \mathrm{mL}$ ) displayed fluctuations of the antioxidant activity; namely, they reacted faster with DPPH in the first 400 seconds. This phenomenon is probably due to the relatively low amounts of antioxidant compounds in the stems. The antioxidant activity of the $M$. officinalis stems solutions was as well concentration-dependent, similar to the leaves extract. 
TABLE 1: The percent of inhibition (AOA) induced by ascorbic acid as compared to M. officinalis leaves and stems ethanolic extracts.

\begin{tabular}{|c|c|c|c|c|c|}
\hline \multicolumn{2}{|c|}{ Ascorbic acid } & \multicolumn{2}{|c|}{ M. officinalis leaves } & \multicolumn{2}{|c|}{ M. officinalis stems } \\
\hline Concentration $[\mathrm{mg} / \mathrm{mL}]$ & $\%$ inhibition & Concentration $[\mathrm{mg} / \mathrm{mL}]$ & $\%$ inhibition & Concentration $[\mathrm{mg} / \mathrm{mL}]$ & $\%$ inhibition \\
\hline 0.1 & 94.17 & 10 & 91.43 & 12.5 & 94.68 \\
\hline 0.08 & 94.65 & 5 & 93.36 & 6 & 76.53 \\
\hline 0.06 & 94.23 & 3 & 91.96 & 4 & 58.20 \\
\hline 0.04 & 93.99 & 1.5 & 59.69 & 2 & 34.73 \\
\hline 0.02 & 80.67 & 0.9 & 52.22 & 1 & 27.82 \\
\hline 0.005 & 27.48 & 0.5 & 36.22 & 0.6 & 31.21 \\
\hline
\end{tabular}

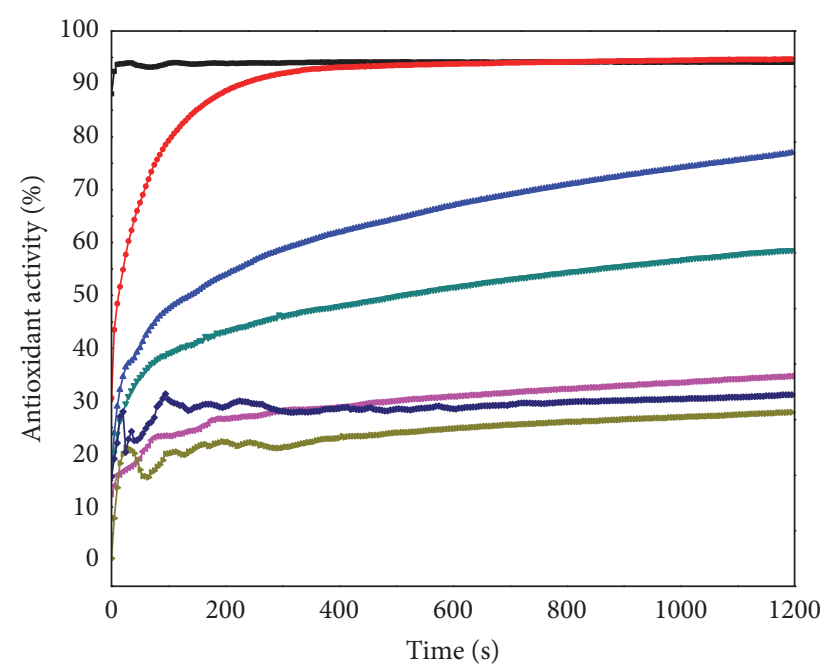

$$
\begin{array}{ll}
\longrightarrow \text { Ascorbic acid } 0.1 \mathrm{mg} / \mathrm{mL} & \longrightarrow C_{3}=2 \mathrm{mg} / \mathrm{mL} \\
\longrightarrow C_{\text {stock }}=12.5 \mathrm{mg} / \mathrm{mL} & \longrightarrow C_{4}=1 \mathrm{mg} / \mathrm{mL} \\
\longrightarrow C_{1}=6 \mathrm{mg} / \mathrm{mL} & \longrightarrow C_{5}=0.6 \mathrm{mg} / \mathrm{mL} \\
\rightarrow C_{2}=4 \mathrm{mg} / \mathrm{mL} &
\end{array}
$$

FIGURE 3: The time-dependent antioxidant activity of the $M$. officinalis stems ethanolic extract.

Our findings are in accordance with the data described in the literature: the compound considered to be responsible for the antioxidant effect is rosmarinic acid, a phenylpropanoid derivative which is present in all organs of the M. officinalis plant [29]. It was established that the antioxidant effect of $M$. officinalis extract is up to ten times stronger than the effect of vitamin C $[28,30]$. The M. officinalis extract exhibits also antinociceptive and anti-inflammatory effects, which are ascribable to rosmarinic acid as well as to terpenoids and flavonoids present in the extract [31].

In Table 1 is displayed the percent of inhibition (AOA) induced by ascorbic acid, M. officinalis leaves, and stems ethanolic extracts.

The inhibition percent was calculated from the following equation:

$$
\% \text { inhibition }=\frac{\left(A_{\text {control }}-A_{\text {sample }}\right)}{A_{\text {control }}} \cdot 100
$$

The $\mathrm{IC}_{50}^{\mathrm{DPH}}$ values for ascorbic acid $\left(\mathrm{IC}_{50}=3.22\right.$. $\left.10^{-6} \pm 0.0002 \mathrm{mg} / \mathrm{mL}\right)$, M. officinalis leaves $\left(\mathrm{IC}_{50}=0.66 \pm\right.$ $0.01 \mathrm{mg} / \mathrm{mL}$ ), and stems $\left(\mathrm{IC}_{50}=10.27 \pm 0.45 \mathrm{mg} / \mathrm{mL}\right.$ ) extracts were also calculated. $\mathrm{IC}_{50}^{\mathrm{DPPH}}$ value represents the concentration of the antioxidant compounds from each sample required to scavenge DPPH radical by $50 \%$. The $\mathrm{IC}_{50}^{\mathrm{DPPH}}$ parameter was determined using GraphPad Prism 5 software.

Koksal and coworkers evaluated the antioxidant activity of two extracts of $M$. officinalis (aqueous and ethanolic), using the DPPH method. They proved that the water extract of M. officinalis has effective antioxidant and radical scavenging activities as compared to ethanolic extract. The $\mathrm{IC}_{50}$ values for both water $(31.4 \mu \mathrm{g} / \mathrm{mL})$ and ethanolic extract $(202.7 \mu \mathrm{g} / \mathrm{mL})$ were, also, established, data that are in agreement with our results [32].

M. officinalis proved to have also anxiolytic effect and circadian activities, due to significant amounts of rosmarinic acid, oleanolic acid, ursolic acid, and triterpenoids [33]. Previous studies reported by our research group indicated that triterpenes are potent antioxidant and antitumor compounds [34].

Pereira and coworkers have demonstrated that $M$. officinalis extract asserts prevention against some diseases associated with oxidative stress, due to the antioxidant activity of phenolic compounds such as quercetin, garlic acid, quercitrin, and rutin [16].

3.2. Total Phenolic Content (TPC). Depending on the plant part used for preparation (leaves or stems), the content of total phenols varied with one order of magnitude. The TPC in the leaves extract was $32.76 \mathrm{mg} \mathrm{GAE} / \mathrm{g}$ dry material, while, in the extract from stems, TPC was much lower (8.4 mg GAE/g dry material). Studies evaluating the TPC of lemon balm extracts show an important variation of results. For example, the methanolic extract obtained from the aerial parts of M. officinalis growing in Romania had a TPC of $22 \mathrm{mg} \mathrm{GAE} / \mathrm{g}$ extract [35]. On the contrary, for the methanolic extract of plant material from Bulgaria (herb) a TPC of $48.86 \mathrm{mg} \mathrm{GAE} / 100 \mathrm{~g}$ dry weight was measured [36]. The variation of TPC values according to the extraction method and the solvent used is also reported in the literature. For the extract obtained by maceration, the TPC content was $90.1 \mathrm{mg} \mathrm{GAE} / \mathrm{g}$ dry material, whereas, for the extract prepared by the means of ultrasounds, TPC was $105.5 \mathrm{mg}$ GAE/g dry material [37]. 


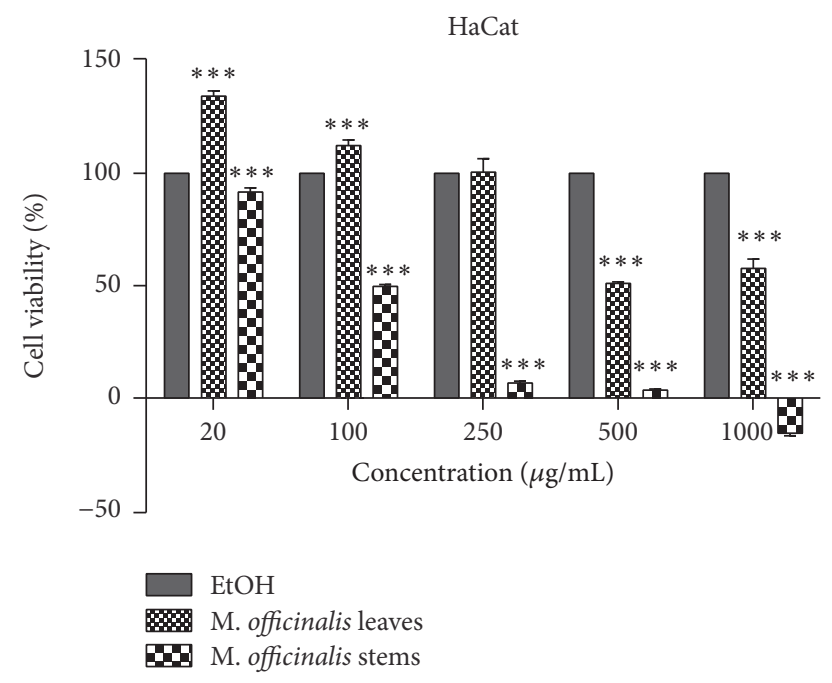

Figure 4: Percentage of viable cells-human keratinocytes (HaCat), after stimulation with $M$. officinalis leaves and stems extracts (20, $100,250,500$, and $1000 \mu \mathrm{g} / \mathrm{mL}$ ) for $24 \mathrm{~h}$. The viability was assessed by using Alamar blue assay and was expressed as percentage of viable cells (\%) related to positive control (cells stimulated with EtOH, the solvent used for obtaining the extracts). Data are expressed as mean values \pm SD of three independent experiments done in triplicate and ${ }^{* * *} p<0.001$ and were calculated by one-way ANOVA followed by Tukey's post hoc test.

The phenolic content of lemon balm extract is also influenced by the solvent used for its preparation. A high phenolic content was estimated for the hydroalcoholic extract from lemon balm leaves (227.6 mg GAE/g dry material) [38].

Phenolic compounds have been investigated in numerous studies for their antioxidant activity which is important in the prevention and therapy of several diseases, including cancer [39]. Previous studies proved that polyphenolic compounds determined a strong antioxidant activity that might influence the biological response [34, 40].

3.3. Cytotoxicity Assessment by the Means of Alamar Blue. One of the aims of the present study consisted in verifying the cytotoxic effect of the extracts on normal (human keratinocytes, HaCat) and breast cancer (MDA-MB-231) cell lines. Five different concentrations were tested $(20,100,250$, 500 , and $1000 \mu \mathrm{g} / \mathrm{mL})$ for $24 \mathrm{~h}$. Our results indicated that the solvent (ethanol 70\%) induced a cytotoxic effect by itself even at the lowest concentration $(20 \mu \mathrm{g} / \mathrm{mL})$ as compared to control cells (unstimulated), this being the reason why the cytotoxicity data were reported to the solvent effect.

The impact of the two types of $M$. officinalis extractsleaves and stems-on normal human keratinocytes viability is presented in Figure 4.

Figure 4 indicates that the $M$. officinalis leaves' ethanolic extract induced a dose-dependent cytotoxicity $\left(\mathrm{IC}_{50}=301.4\right.$ $\pm 10.26 \mu \mathrm{g} / \mathrm{mL}$ ), the highest concentrations tested (500 and $1000 \mu \mathrm{g} / \mathrm{mL}$ ) being toxic for HaCat cells when compared to solvent, whereas the low concentrations $(20,100$, and $250 \mu \mathrm{g} / \mathrm{mL}$ ) were devoid of toxicity.

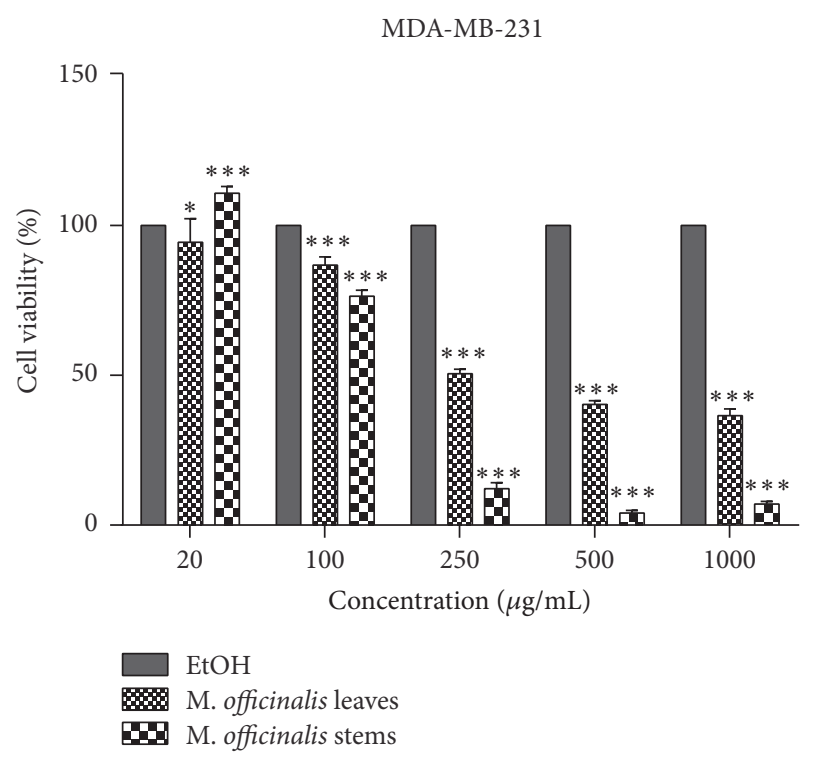

FIGURE 5: Percentage of viable cells-breast cancer cells (MDA-MB231), after stimulation with $M$. officinalis leaves and stems extracts $(20,100,250,500$, and $1000 \mu \mathrm{g} / \mathrm{mL})$ for $24 \mathrm{~h}$. The viability was assessed by using Alamar blue assay and was expressed as percentage of viable cells (\%) related to positive control (cells stimulated with $\mathrm{EtOH}$, the solvent used for obtaining the extracts). Data are expressed as mean values \pm SD of three independent experiments done in triplicate and ${ }^{* * *} p<0.001$ and were calculated by one-way ANOVA followed by Tukey's post hoc test.

In the case of M. officinalis stems extracts (Figure 4), the situation was quite different, the cytotoxic effect being observed at concentration of $100 \mu \mathrm{g} / \mathrm{mL}\left(\mathrm{IC}_{50}=109.63 \pm\right.$ $7.68 \mu \mathrm{g} / \mathrm{mL}$ ). After stimulation with 250 and $500 \mu \mathrm{g} / \mathrm{mL}$, the percentage of viable cells recorded was lower than $10 \%$, and the highest concentration tested $(1000 \mu \mathrm{g} / \mathrm{mL})$ induced a negative rate.

The effect of the two extracts on breast cancer cells (MDAMB-231) was also verified (Figure 5). M. officinalis leaves' extract induced a cytotoxic effect starting with $100 \mu \mathrm{g} / \mathrm{mL}$ $\left(\mathrm{IC}_{50}=196.66 \pm 13.93 \mu \mathrm{g} / \mathrm{mL}\right)$, the most significant cytotoxic effects being recorded for 500 and $1000 \mu \mathrm{g} / \mathrm{mL}$ (Figure 5).

$M$. officinalis stems' extract exerted a stronger cytotoxic effect on MDA-MB-231 cells (Figure 5) as compared to the $M$. officinalis leaves extract, the percentage of viable cells being more reduced for most of the concentrations tested $\left(\mathrm{IC}_{50}\right.$ $=103.73 \pm 6.69 \mu \mathrm{g} / \mathrm{mL}$ ), the strongest cytotoxic effect being induced by the $500 \mu \mathrm{g} / \mathrm{mL}$ concentration (4.08\%).

Based on the results obtained, it could be stated that the active principles of both $M$. officinalis ethanolic extracts exerted antitumor activity by reducing the viability of breast adenocarcinoma cells at concentrations higher than $100 \mu \mathrm{g} / \mathrm{mL}$.

Similar results were described by Saraydin and coworkers when an aqueous $M$. officinalis extract was tested on different breast cancer cells (MCF-7, MDA-MB-231, and MDA-MB468) [41]. The cytotoxic effects of $M$. officinalis were also proved on human colon cancer cells-HCT-116 [18]. A recent 

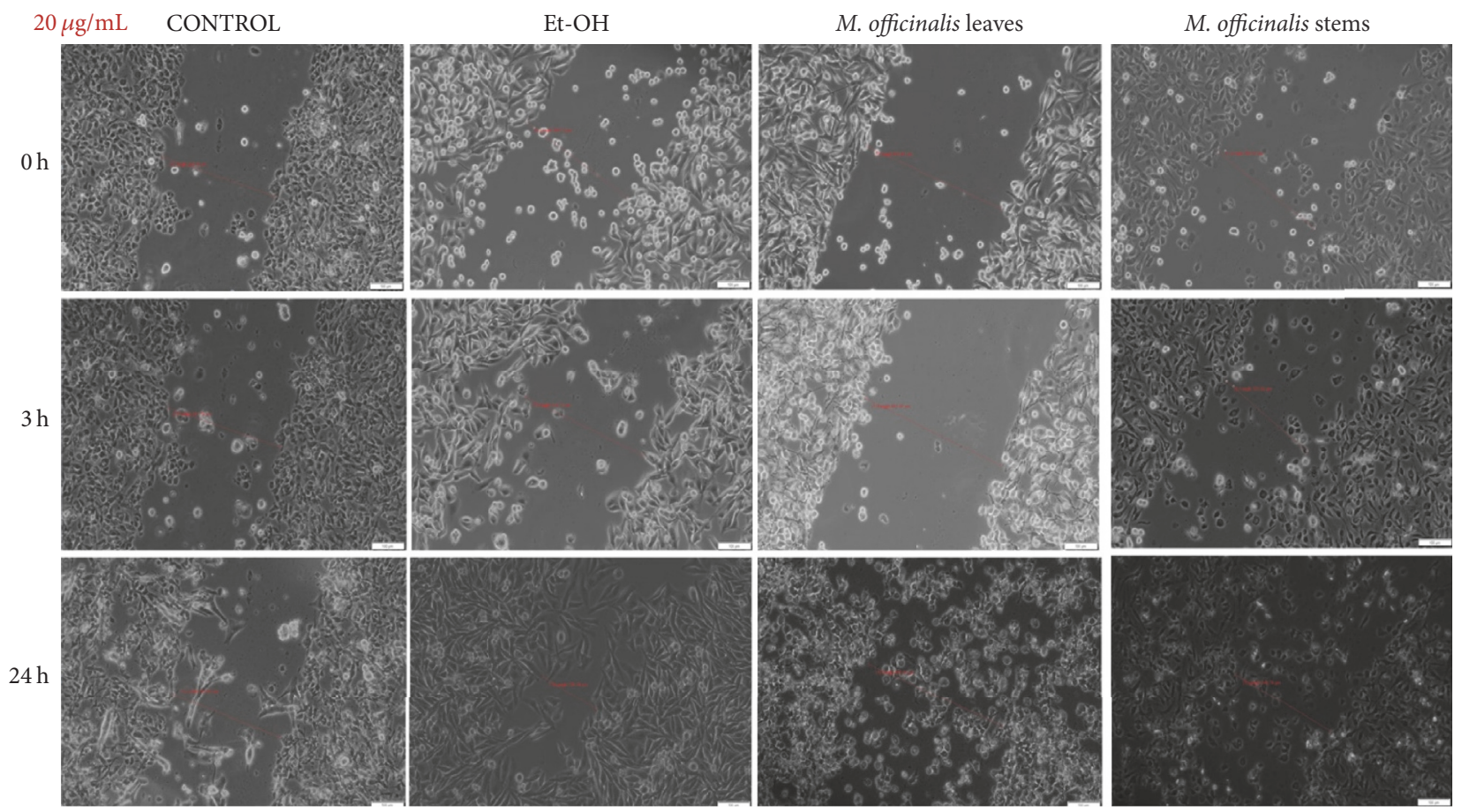

FIGURE 6: The effect of M. officinalis ethanolic extracts $(20 \mu \mathrm{g} / \mathrm{mL})$ on HaCat cells' migration and proliferation. The pictures were taken at 0 , 3 , and $24 \mathrm{~h}$ after stimulation.

study showed that, at a concentration of $50 \mu \mathrm{g} / \mathrm{mL}$, an ethanolic extract of $M$. officinalis induced a low growth inhibition percentage (under 15\%) to a panel of human cancer cell lines (melanoma, breast cancer, colon cancer, osteosarcoma, leukemia, etc.) [42]. Jahanban-Esfahlan and collaborators proved the antiproliferative properties of a hydroalcoholic $M$. officinalis extract on lung (A549), breast (MCF-7), ovarian (SKOV3), and prostate (PC-3) cancer cells, the cytotoxic effect being tumor type specific [40].

3.4. The Antimigratory Effect via Wound Healing Assay Method. The ability of cancer cells to migrate is well-known as well as the key role of this process in tumor progression and metastasis. In order to verify the antimigratory effect of the M. officinalis leaves and stems extracts by the means of scratch assay, the smallest concentrations were tested $(20,100$, and $250 \mu \mathrm{g} / \mathrm{mL}$ ), concentrations that proved to be less cytotoxic for the cells. It can be observed in Figure 6 that M. officinalis stems extract, at the concentration of $20 \mu \mathrm{g} / \mathrm{mL}$, exhibited a superior antimigratory effect on $\mathrm{HaCat}$ cells at 24 hours after stimulation, when compared with M. officinalis leaves extract at the same concentration.

As showed in Figure 7, both M. officinalis extracts at the concentration of $100 \mu \mathrm{g} / \mathrm{mL}$ manifested antimigratory effect, at $3 \mathrm{~h}$ after stimulation. After $24 \mathrm{~h}$, HaCat cells became detached and changed their shape and morphology, the most significant changes being observed after $M$. officinalis leaves extract stimulation. In addition, pictures indicated that ethanol (solvent) at concentration $100 \mu \mathrm{g} / \mathrm{mL}$ did not affect migration and proliferation of HaCat cells (Figure 7).
Stimulation of HaCat cells with $250 \mu \mathrm{g} / \mathrm{mL}$ of $M$. officinalis ethanolic extracts led to a significant antimigratory effect observed after $3 \mathrm{~h}$ of stimulation (Figure 8). Moreover, as it can be seen in the pictures, even at $3 \mathrm{~h}$ after stimulation there were detached cells that were floating in the medium, with round shape characteristic to apoptotic cells, the number of these cells becoming higher at $24 \mathrm{~h}$ after stimulation, indicating the cytotoxic properties of these extracts, data that are consistent with the results obtained by cell viability assay. At $24 \mathrm{~h}$ after stimulation, the shape and the morphology of the cells that were attached to the plate seemed to be modified. The ethanol tested in the same concentration $(250 \mu \mathrm{g} / \mathrm{mL})$ as positive control did not have a negative impact on proliferation of keratinocyte cell line $24 \mathrm{~h}$ after stimulation (Figure 8).

M. officinalis ethanolic extracts' stimulation revealed an inhibitory effect on MDA-MB-231 cells migration and proliferation (Figures 9-11). From the comparison of control pictures, it can be observed that MDA-MB-231 breast adenocarcinoma cells possess invasive properties, the created gaps becoming filled by cells at $24 \mathrm{~h}$ (the size range of the gaps varied from $488.23 \mu \mathrm{m}$ at $0 \mathrm{~h}$ to $169.82 \mu \mathrm{m}$ at $24 \mathrm{~h}$ ). The use of ethanol as positive control did not influence the migration and proliferation of MDA-MB-231 cells at 20 and $100 \mu \mathrm{g} / \mathrm{mL}$ (Figures 9 and 10), whereas at $250 \mu \mathrm{g} / \mathrm{mL}$ some cells were observed floating in the medium at $24 \mathrm{~h}$ (Figure 11).

The antimigratory effects of both $M$. officinalis extracts were detected from $3 \mathrm{~h}$ after stimulation with all concentrations $(20,100$, and $250 \mu \mathrm{g} / \mathrm{mL})$. Changes in the breast cancer cells shape and morphology could be observed after 


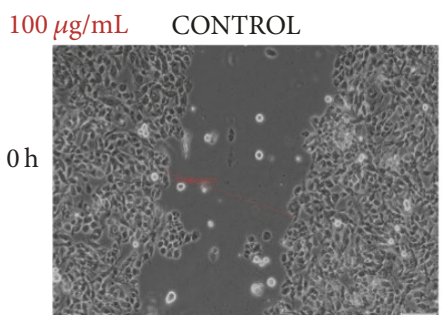

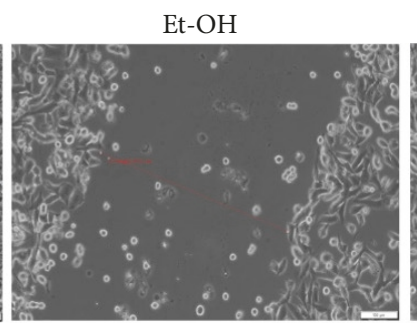

M. officinalis leaves
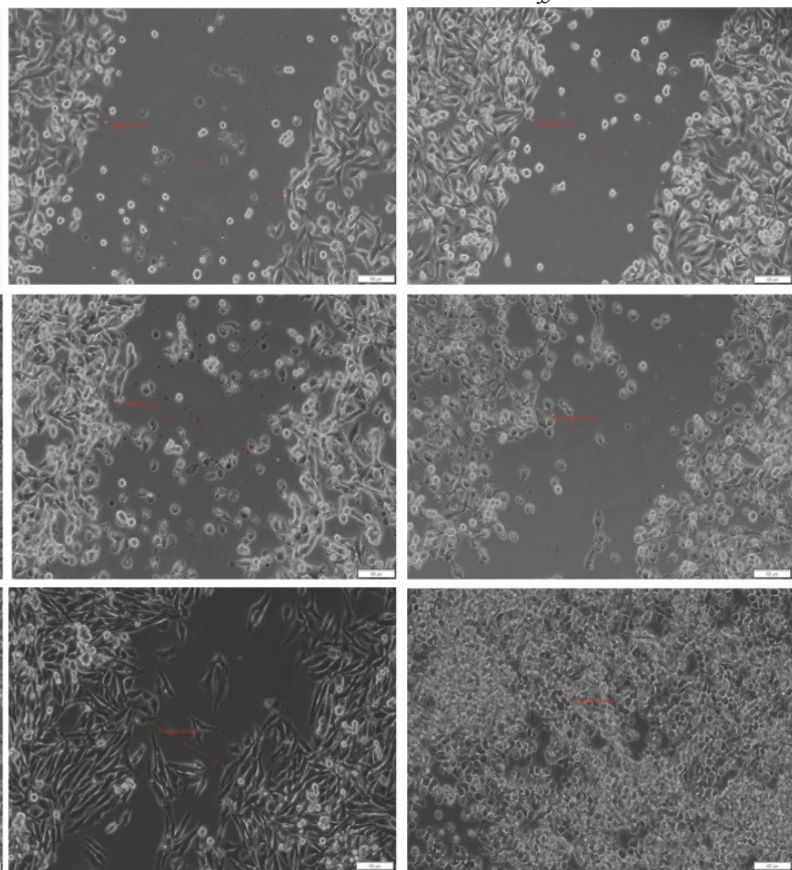
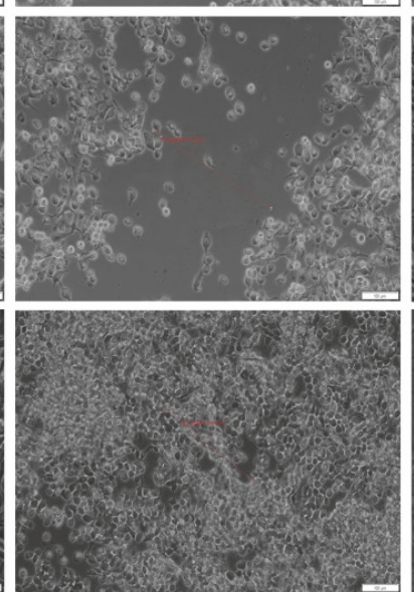

M. officinalis stems
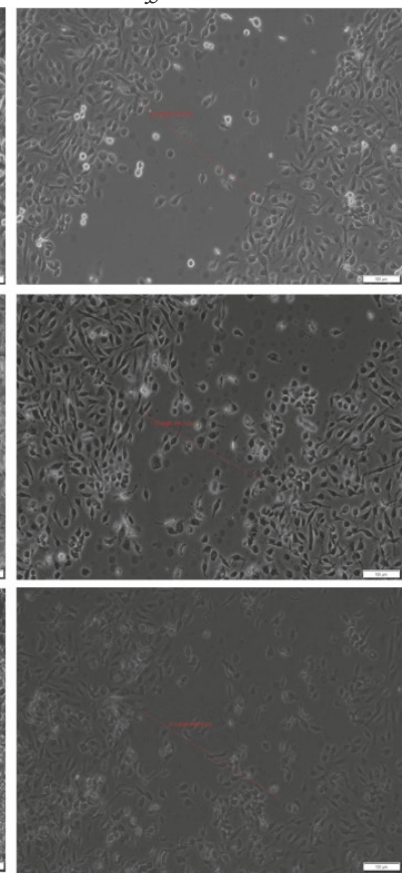

FigURE 7: The effect of M. officinalis ethanolic extracts $(100 \mu \mathrm{g} / \mathrm{mL})$ on HaCat cells' migration and proliferation. The pictures were taken at 0 , 3 , and $24 \mathrm{~h}$ after stimulation.

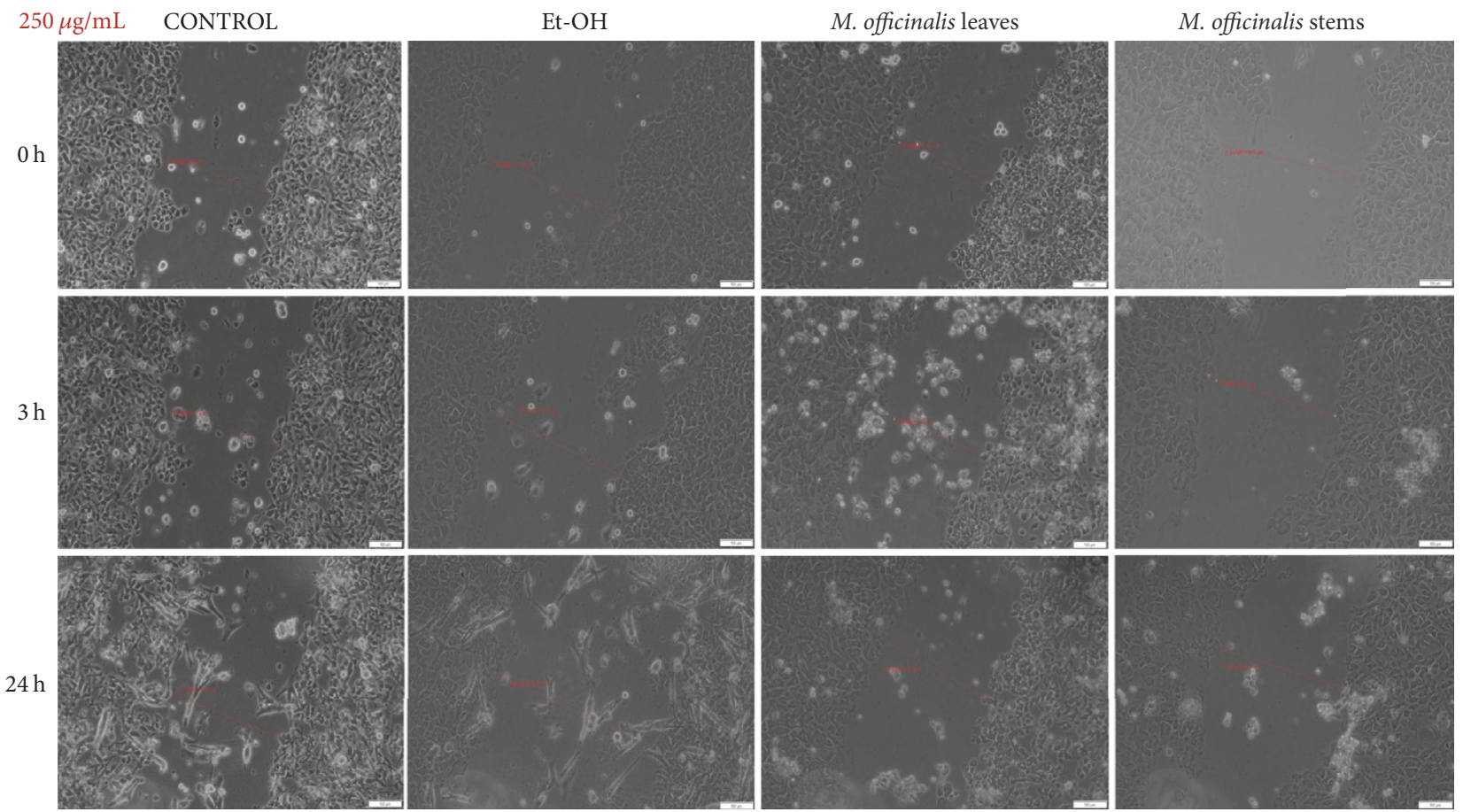

FigURE 8: The effect of $M$. officinalis ethanolic extracts $(250 \mu \mathrm{g} / \mathrm{mL})$ on HaCat cells' migration and proliferation. The pictures were taken at 0,3 , and $24 \mathrm{~h}$ after stimulation. 

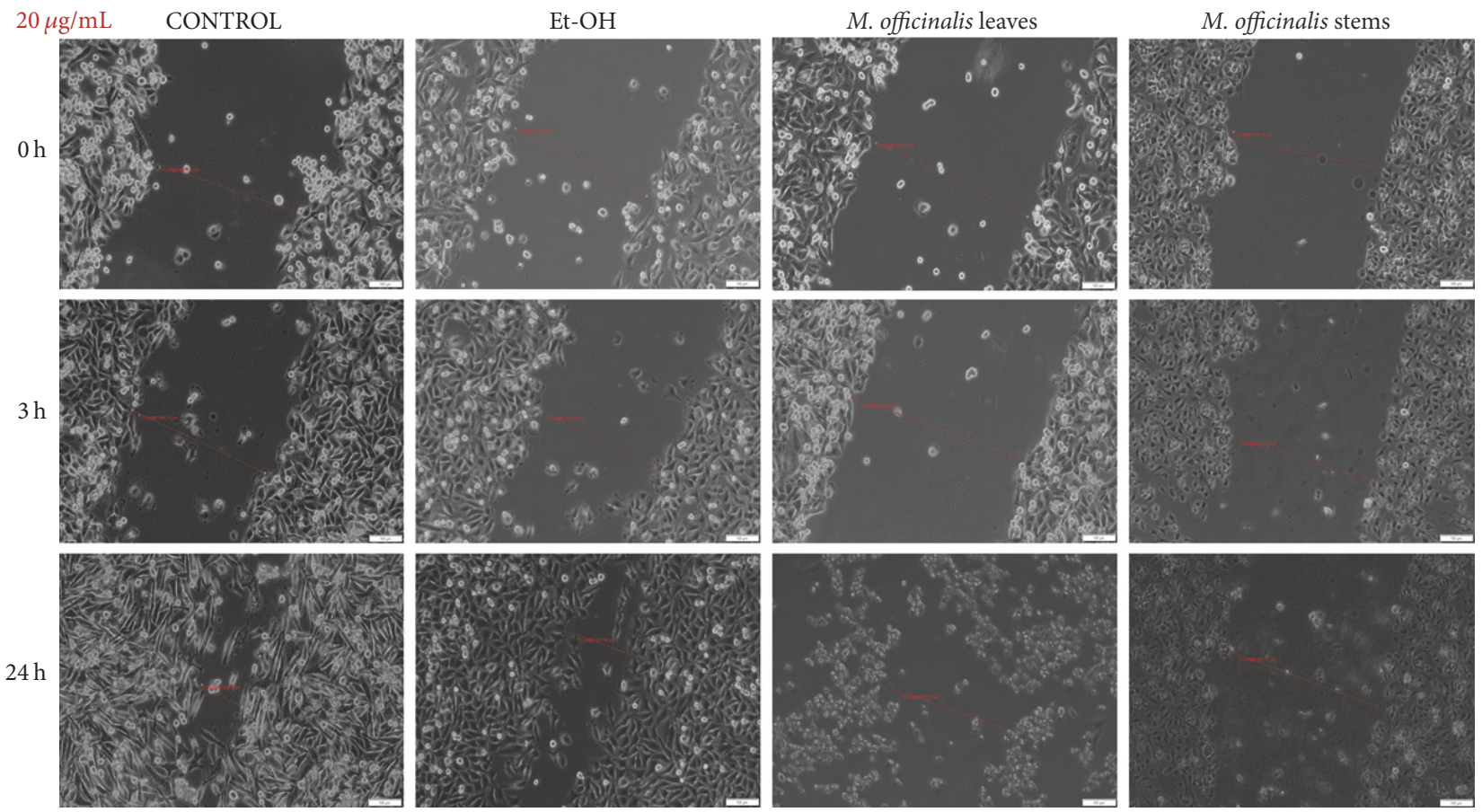

Figure 9: The effect of $M$. officinalis ethanolic extracts $(20 \mu \mathrm{g} / \mathrm{mL})$ on MDA-MB-231 cells' migration and proliferation. The pictures were taken at 0,3 , and $24 \mathrm{~h}$ after stimulation.
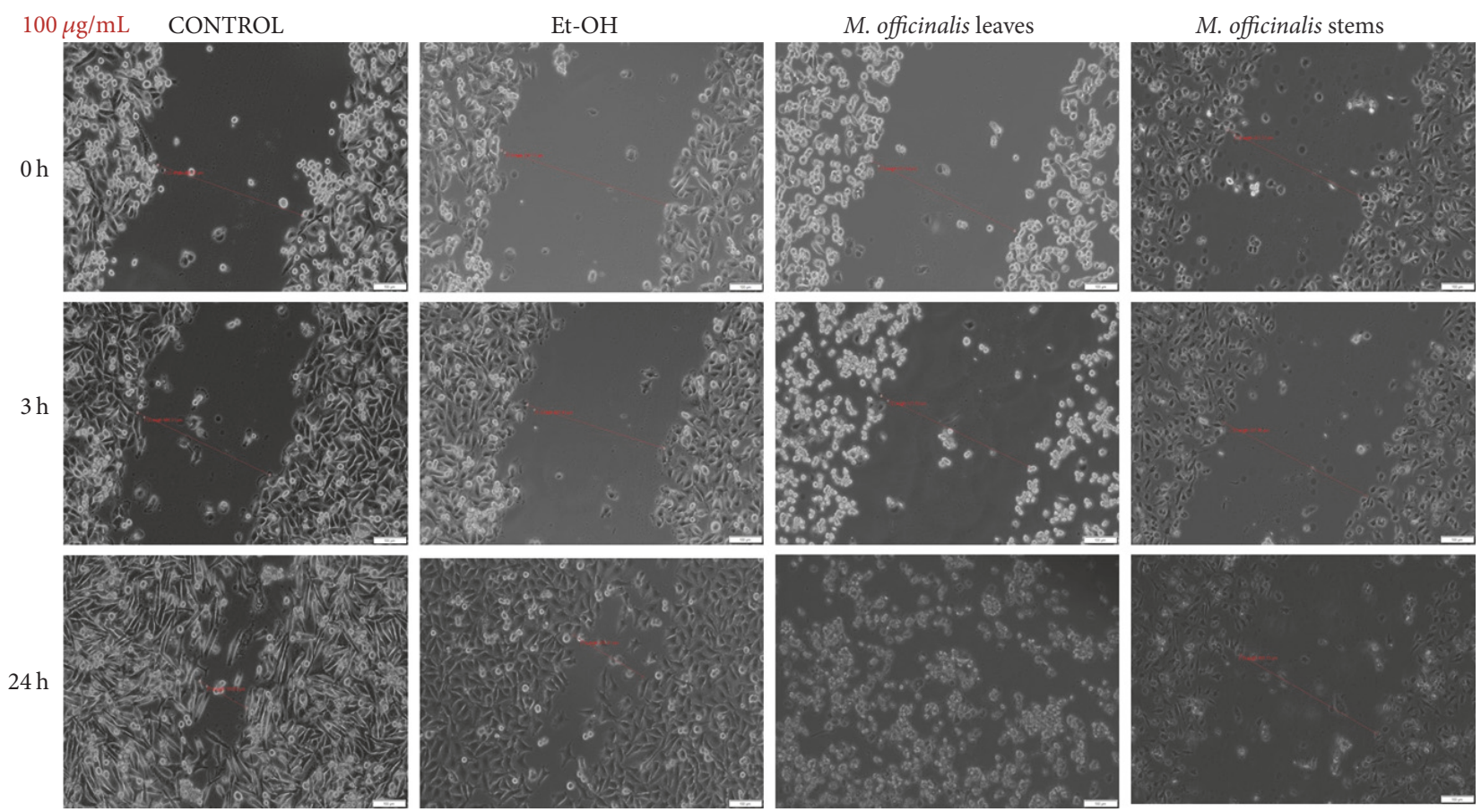

FIGURE 10: The effect of $M$. officinalis ethanolic extracts $(100 \mu \mathrm{g} / \mathrm{mL})$ on MDA-MB-231 cells' migration and proliferation. The pictures were taken at 0,3 , and $24 \mathrm{~h}$ after stimulation.

$24 \mathrm{~h}$, even at the lowest concentration tested $(20 \mu \mathrm{g} / \mathrm{mL})$. These effects were more pregnant after stimulation with M. officinalis leaves extract (Figures 9-11). The presence of detached and round cells after stimulation indicated the cytotoxic effect of these extracts, results that are in agreement with the ones recorded by the means of Alamar blue assay.

The in vitro tests performed in the present study denoted that both $M$. officinalis ethanolic extracts exerted 
$250 \mu \mathrm{g} / \mathrm{mL} \quad$ CONTROL
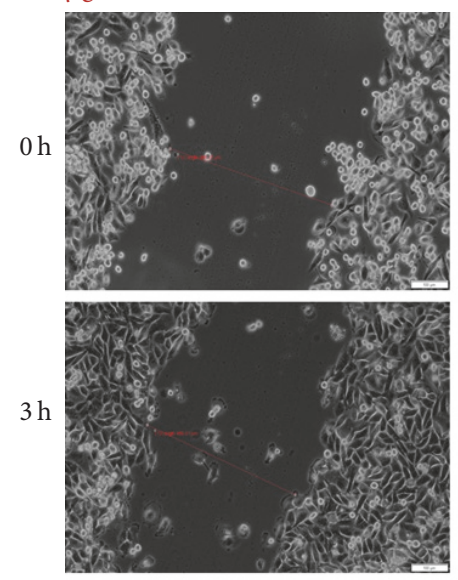

$24 \mathrm{~h}$

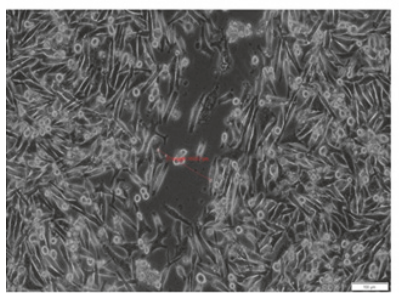

Et-OH
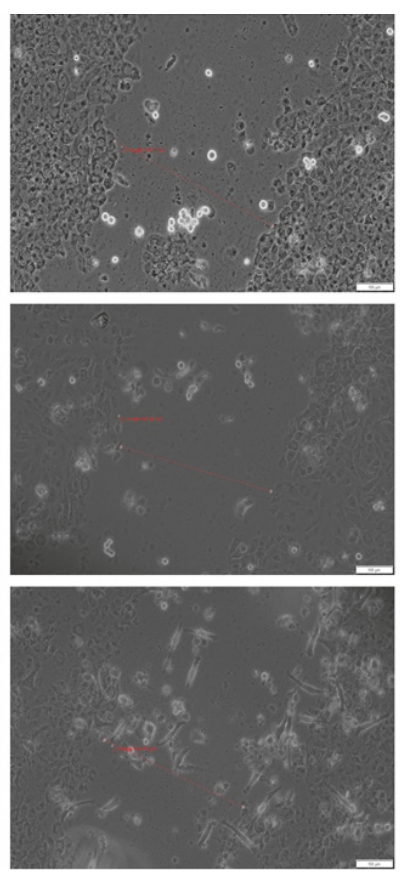

M. officinalis leaves
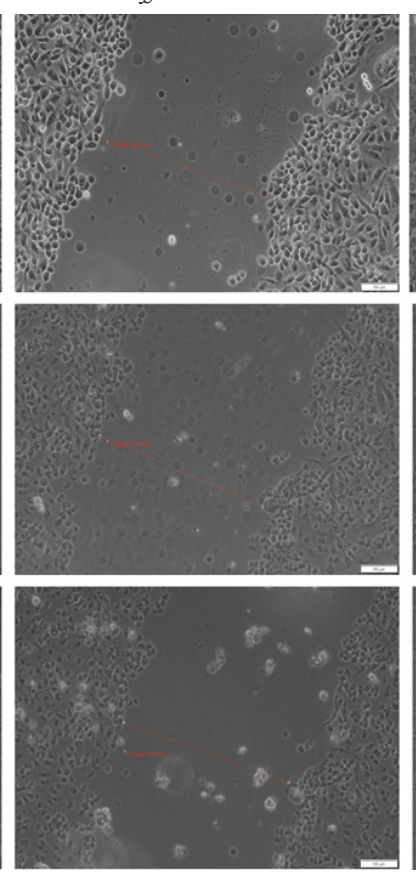

M. officinalis stems
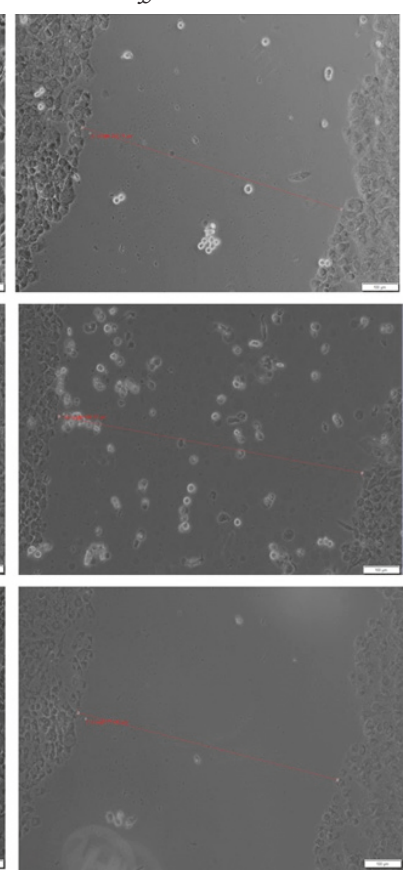

Figure 11: The effect of $M$. officinalis ethanolic extracts $(250 \mu \mathrm{g} / \mathrm{mL})$ on MDA-MB-231 cells' migration and proliferation. The pictures were taken at 0,3 , and $24 \mathrm{~h}$ after stimulation.

cytotoxic effects on healthy cells (only at the highest concentrations $-250,500$, and $1000 \mu \mathrm{g} / \mathrm{mL}$ ), but also, on breast cancer cells, the cytotoxicity being induced starting with $100 \mu \mathrm{g} / \mathrm{mL}$, the strongest cytotoxic effect was exhibited by the $M$. officinalis stems extract. In addition, the lowest concentrations of $M$. officinalis ethanolic extracts $(20,100$, and $250 \mu \mathrm{g} / \mathrm{mL}$ ) determined an inhibitory effect on migration and proliferation of both types of cells.

According to previous studies, $M$. officinalis extract was tested on colon cancer cells and breast cancer cells and proved to be cytotoxic. M. officinalis alcoholic extract induced apoptosis and inhibited proliferation of the colon cancer cells through generation of reactive species of oxygen [15]. Moreover, it was established that rosmarinic acid from $M$. officinalis extract was responsible for the antimigratory effect of colon cancer cells HCT-116 [18].

M. officinalis extract proved to have antiproliferative activity even on hormone-dependent cells [40]. The study accomplished by Saraydin and coworkers [41] on breast cancer cells (MCF-7, MDA-MB-468, and MDA-MB-231) corroborates our results, according to which $M$. officinalis extract may represent the therapeutic alternative in chemoprevention of breast cancer. Nevertheless, it is imperiously necessary for these effects to be sustained by in vivo studies.

The main observation is that antiproliferative and antioxidant activity are increased in a direct relation with extract concentration. M. officinalis ethanolic extracts developed a positive effective/toxic relationship on human breast carcinoma MDA-MB-231 in vitro. Anyway the concentrations applied on experiments were not very increased and this led to the idea that $M$. officinalis ethanolic extracts are very active in human breast carcinoma data that are related to other reported information [41].

\section{Conclusions}

The present study undertakes an evaluation of cytotoxic and antiproliferative effects of extracts obtained from the leaves and stems of lemon balm, with a special focus on breast cancer cells (MDA-MB-231). These extracts are characterized with regard to their content in total phenolic compounds and antioxidant activities; the extracts from leaves display a higher content in antioxidant phytocompounds and hence a higher bioactivity against free radicals. Both extracts from leaves and from stems demonstrated relevant cytotoxic effects. However, their profile is different. While leaf extracts are selectively more cytotoxic against cancer cells than against normal $\mathrm{HaCat}$ cells, stem extracts have a higher cytotoxic activity against MDA-MB-231 cells but displayed a lower selectivity when compared to healthy cells. The ratio of activity and toxicity for M. officinalis extracts is positive and the antitumor activity is significant. These data represent the background for further in vitro studies required to elucidate the antitumor mechanism of action.

\section{Conflicts of Interest}

The authors declare that there are no conflicts of interest regarding the publication of this paper.

\section{Authors' Contributions}

Elena-Alina Moacă and Claudia Farcaş contributed equally. 


\section{Acknowledgments}

This work was supported by an Internal Grant at University of Medicine and Pharmacy "Victor Babes" Timisoara, Grant IIIC5-PCFI-2017/2018-04 ROINEXTRAMAM (Project Manager: Ştefana Avram).

\section{References}

[1] S. Miraj, N. Azizi, and S. Kiani, "A review of chemical components and pharmacological effects of Melissa officinalis L," Der Pharmacia Lettre, vol. 8, no. 6, pp. 229-237, 2016.

[2] P. Rasmussen, "Lemon balm: Melissa officinalis; also known as lemon balm, bee balm, garden balm, Melissa, melissengeist," Journal of Primary Health Care, vol. 3, no. 2, pp. 165-166, 2011.

[3] N. C. de Carvalho, M. J. F. Corrêa-Angeloni, D. D. Leffa et al., "Evaluation of the genotoxic and antigenotoxic potential of Melissa officinalis in mice," Genetics and Molecular Biology, vol. 34, no. 2, pp. 290-297, 2011.

[4] H.-J. Jun, J. H. Lee, Y. Jia et al., "Melissa officinalis essential oil reduces plasma Triglycerides in human apolipoprotein E2 transgenic mice by inhibiting sterol regulatory element-binding protein-1c-dependent fatty acid synthesis," Journal of Nutrition, vol. 142, no. 3, pp. 432-440, 2012.

[5] E. N. Martins, N. T. C. Pessano, L. Leal et al., "Protective effect of Melissa officinalis aqueous extract against Mn-induced oxidative stress in chronically exposed mice," Brain Research Bulletin, vol. 87, no. 1, pp. 74-79, 2012.

[6] M. Bayat, A. A. Azami Tameh, M. H. Ghahremani et al., "Neuroprotective properties of Melissa officinalis after hypoxicischemic injury both in vitro and in vivo," DARU Journal of Pharmaceutical Sciences, vol. 20, article 42, 2012.

[7] J. U. Bhat, Q. Nizami, M. Aslam et al., "Antiepileptic activity of the whole plant extract of Melissa officinalis in Swiss albino mice," International Journal of Pharmaceutical Sciences and Research, vol. 3, no. 3, pp. 886-889, 2012.

[8] A. Zarei, S. Changizi Ashtiyani, S. Taheri, and F. Rasekh, "Comparison between effects of different doses of Melissa officinalis and atorvastatin on the activity of liver enzymes in hypercholesterolemia rats," Avicenna Journal of Phytomedicine, vol. 4, no. 1, pp. 15-23, 2014.

[9] H. Moradkhani, E. Sargsyan, H. Bibak et al., "Melissa officinalis L., a valuable medicine plant: a review," Journal of Medicinal Plants Research, vol. 4, no. 25, pp. 2753-2759, 2010.

[10] A. Shakeri, A. Sahebkar, and B. Javadi, "Melissa officinalis L. - A review of its traditional uses, phytochemistry and pharmacology," Journal of Ethnopharmacology, vol. 188, pp. 204-228, 2016.

[11] A. Arceusz and M. Wesolowski, "Quality consistency evaluation of Melissa officinalis L. commercial herbs by HPLC fingerprint and quantitation of selected phenolic acids," Journal of Pharmaceutical and Biomedical Analysis, vol. 83, pp. 215-220, 2013.

[12] C. Weidner, S. J. Wowro, A. Freiwald et al., "Lemon balm extract causes potent antihyperglycemic and antihyperlipidemic effects in insulin-resistant obese mice," Molecular Nutrition \& Food Research, vol. 58, no. 4, pp. 903-907, 2014.

[13] A. Zarei, S. Changizi-Ashtiyani, S. Taheri, and N. Hosseini, "A Brief Overview of the Effects of Melissa officinalis L. Extract on the Function of Various Body Organs," Zahedan Journal of Research in Medical Sciences, vol. 17, no. 7, 2015.
[14] M. Mahita, "Identification of a Novel GABAA Receptor Channel Ligand Derived from Melissa officinalis and Lavandula angustifolia Essential Oils," European Journal of Medicinal Plants, vol. 4, no. 7, pp. 810-818, 2014.

[15] C. Weidner, M. Rousseau, A. Plauth et al., "Melissa officinalis extract induces apoptosis and inhibits proliferation in colon cancer cells through formation of reactive oxygen species," Phytomedicine, vol. 22, no. 2, pp. 262-270, 2015.

[16] R. P. Pereira, R. Fachinetto, A. De Souza Prestes et al., "Antioxidant effects of different extracts from Melissa officinalis, Matricaria recutita and Cymbopogon citratus," Neurochemical Research, vol. 34, no. 5, pp. 973-983, 2009.

[17] J.-T. Lin, Y.-C. Chen, Y.-C. Lee, C.-W. R. Hou, F.-L. Chen, and D.-J. Yang, "Antioxidant, anti-proliferative and cyclooxygenase2 inhibitory activities of ethanolic extracts from lemon balm (Melissa officinalis L.) leaves," LWT - Food Science and Technology, vol. 49, no. 1, pp. 1-7, 2012.

[18] M. A. Encalada, K. M. Hoyos, S. Rehecho et al., "Antiproliferative effect of Melissa officinalis on human colon cancer cell line," Plant Foods for Human Nutrition, vol. 66, no. 4, pp. 328-334, 2011.

[19] S. Sharafzadeh, M. Khosh-Khui, and K. Javidnia, "Aroma profile of leaf and stem of lemon balm (Melissa officinalis L.) grown under greenhouse conditions," Advances in Environmental Biology, vol. 5, no. 4, pp. 547-550, 2011.

[20] T. Mencherini, P. Picerno, P. Russo, M. Meloni, and R. Aquino, "Composition of the fresh leaves and stems of Melissa officinalis and evaluation of skin irritation in a reconstituted human epidermis model," Journal of Natural Products, vol. 72, no. 8, pp. 1512-1515, 2009.

[21] J. P. Kamdem, A. Adeniran, A. A. Boligon et al., "Antioxidant activity, genotoxicity and cytotoxicity evaluation of lemon balm (Melissa officinalis L.) ethanolic extract: Its potential role in neuroprotection," Industrial Crops and Products, vol. 51, pp. 2634, 2013.

[22] L. Manzocco, M. Anese, and M. C. Nicoli, "Antioxidant properties of tea extracts as affected by processing," LWT-Food Science and Technology, vol. 31, no. 7-8, pp. 694-698, 1998.

[23] J. C. Sánchez-Rangel, J. Benavides, J. B. Heredia, L. CisnerosZevallos, and D. A. Jacobo-Velázquez, "The Folin-Ciocalteu assay revisited: Improvement of its specificity for total phenolic content determination," Analytical Methods, vol. 5, no. 21, pp. 5990-5999, 2013.

[24] A. Blainski, G. C. Lopes, and J. C. P. De Mello, "Application and analysis of the folin ciocalteu method for the determination of the total phenolic content from Limonium Brasiliense L.", Molecules, vol. 18, no. 6, pp. 6852-6865, 2013.

[25] C. Soica, C. Oprean, F. Borcan et al., "The Synergistic Biologic Activity of Oleanolic and Ursolic Acids in Complex with Hydroxypropyl- $\gamma$-Cyclodextrin," Molecules, vol. 19, no. 4, pp. 4924-4940, 2014.

[26] D. Coricovac, E. Moacă, I. Pinzaru et al., "Biocompatible Colloidal Suspensions Based on Magnetic Iron Oxide Nanoparticles: Synthesis, Characterization and Toxicological Profile," Frontiers in Pharmacology, vol. 8, 2017.

[27] A. Bounihi, G. Hajjaj, R. Alnamer, Y. Cherrah, and A. Zellou, "In vivo potential anti-inflammatory activity of Melissa officinalis L. essential oil," Advances in Pharmacological Sciences, vol. 2013, Article ID 101759, 7 pages, 2013.

[28] K. Dastmalchi, H. J. D. Dorman, P. P. Oinonen, Y. Darwis, I. Laakso, and R. Hiltunen, "Chemical composition and in vitro 
antioxidative activity of a lemon balm (Melissa officinalis L.) extract," LWT - Food Science and Technology, vol. 41, no. 3, pp. 391-400, 2008.

[29] C. Weitzel and M. Petersen, "Cloning and characterisation of rosmarinic acid synthase from Melissa officinalis L.," Phytochemistry, vol. 72, no. 7, pp. 572-578, 2011.

[30] M. B. Rassouli, N. Ghayour, M. Afsharian et al., "The protective effects of Melissa officinalis leaves usage on learning disorder induced by lead acetate administration during pre and postnatal periods in rats," Arak Medical University Journal, vol. 13, no. 1, pp. 97-104, 2010.

[31] H. M. Gorgi, A. A. Vafaee, A. RashidiPoor et al., "The role of opioid receptors on anxiolytic effects of the aqueous extract of Melissa officinalis in mice," Razi Journal of Medical Sciences, vol. 12, no. 47, pp. 145-153, 2005.

[32] E. Koksal, E. Bursal, E. Dikici, F. Tozoglu, and I. Gulcin, "Antioxidant activity of Melissa officinalis leaves," Journal of Medicinal Plants Research, vol. 5, no. 2, pp. 217-222, 2011.

[33] A. Ibarra, N. Feuillere, M. Roller, E. Lesburgere, and D. Beracochea, "Effects of chronic administration of Melissa officinalis L. extract on anxiety-like reactivity and on circadian and exploratory activities in mice," Phytomedicine, vol. 17, no. 6, pp. 397-403, 2010.

[34] C. A. Dehelean, L. Vlase, C. Peev, D. Antal, and C. Şoica, "Comparative analysis of polyphenols content from birch tree foliar buds and leaves by HPLC-UV-MS," CHEMISTRY MAGAZINE, vol. 57, no. 8, pp. 862-865, 2006.

[35] A. Armatu, S. Colceru-Mihul, C. Bubueanu, E. Draghici, and L. Pirvu, "Evaluation of antioxidant and free scavenging potential of some Lamiaceae species growing in Romania," Romanian Biotechnological Letters, vol. 15, no. 3, pp. 5274-5280, 2010.

[36] M. Atanassova, S. Georgieva, and K. Ivancheva, "Total phenolic and total flavonoid contents, antioxidant capacity and biological contaminants in medicinal herbs," Journal of the University of Chemical Technology and Metallurgy, vol. 46, no. 1, pp. 81-88, 2011.

[37] A. E. Ince, S. Şahin, and S. G. Şümnü, "Extraction of phenolic compounds from melissa using microwave and ultrasound," Turkish Journal of Agriculture and Forestry, vol. 37, no. 1, pp. 6975, 2013.

[38] M.-T. Moradi, A. Karimi, S. Alidadi, and L. Hashemi, "In vitro anti-adenovirus activity, antioxidant potential and total phenolic compounds of Melissa officinalis L. (lemon balm) extract," International Journal of Pharmacognosy and Phytochemical Research, vol. 8, no. 9, pp. 1471-1477, 2016.

[39] A.-N. Li, S. Li, Y.-J. Zhang, X.-R. Xu, Y.-M. Chen, and H.-B. $\mathrm{Li}$, "Resources and biological activities of natural polyphenols," Nutrients, vol. 6, no. 12, pp. 6020-6047, 2014.

[40] A. Jahanban-Esfahlan, S. Modaeinama, M. Abasi, M. M. Abbasi, and R. Jahanban-Esfahlan, "Anti proliferative properties of Melissa officinalis in different human cancer cells," Asian Pacific Journal of Cancer Prevention, vol. 16, no. 14, pp. 5703-5707, 2015.

[41] S. U. Saraydin, E. Tuncer, B. Tepe et al., "Antitumoral effects of melissa officinalis on breast cancer in vitro and in vivo," Asian Pacific Journal of Cancer Prevention, vol. 13, no. 6, pp. 27652770, 2012.

[42] V. R. Lombardi, I. Carrera, and R. Cacabelos, "In Vitro Screening for Cytotoxic Activity of Herbal Extracts," EvidenceBased Complementary and Alternative Medicine, vol. 2017, pp. 1-8, 2017. 


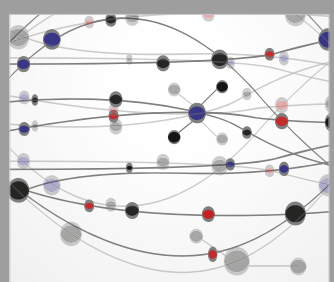

The Scientific World Journal
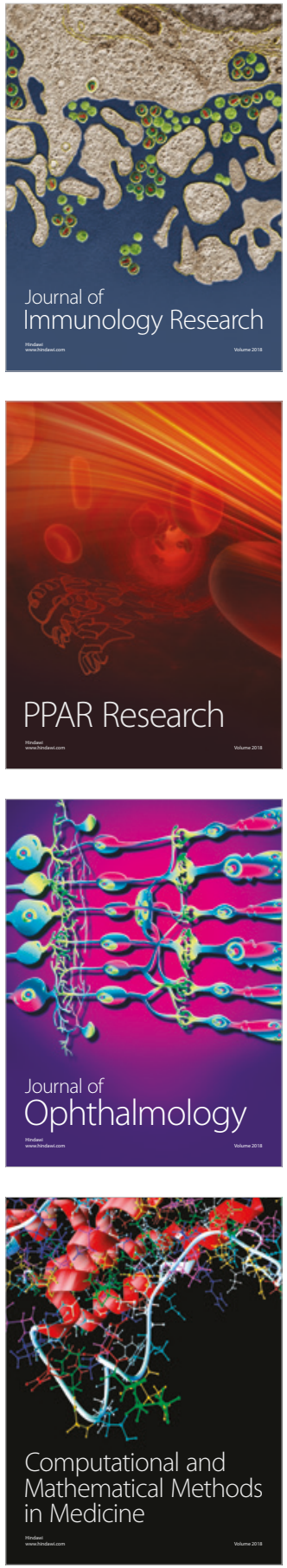

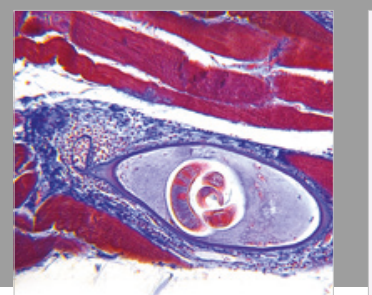

Gastroenterology Research and Practice

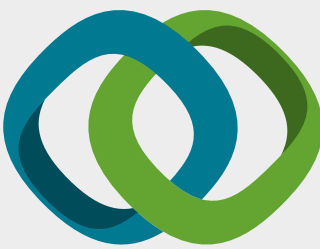

\section{Hindawi}

Submit your manuscripts at

www.hindawi.com
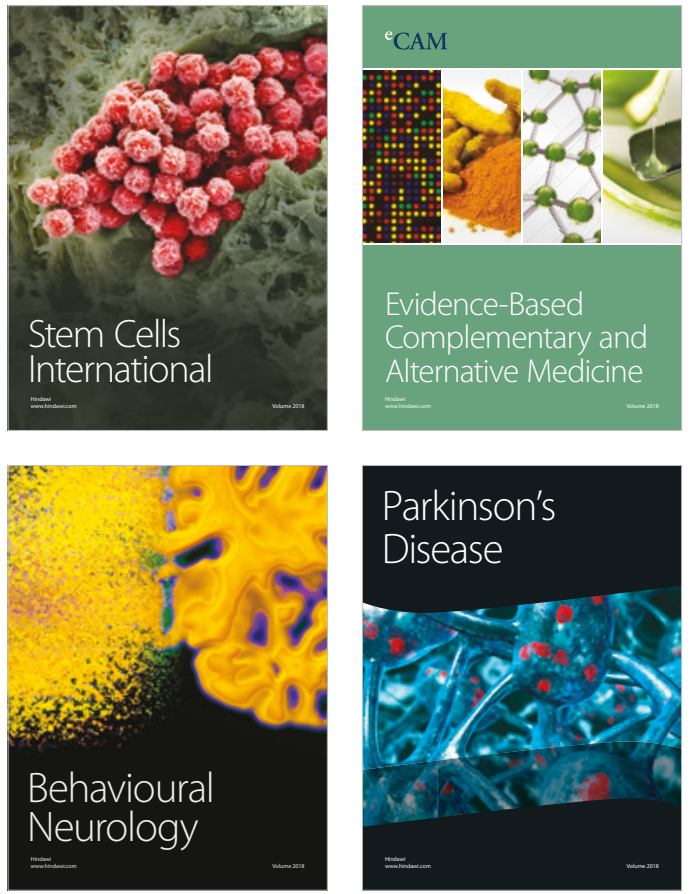

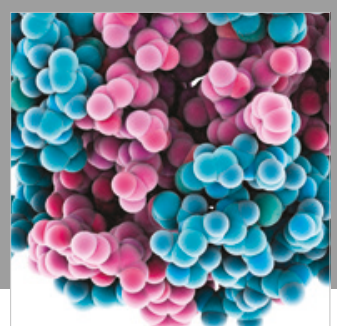

ournal of

Diabetes Research

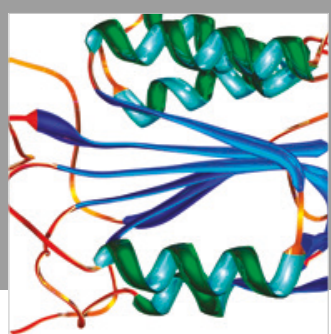

Disease Markers
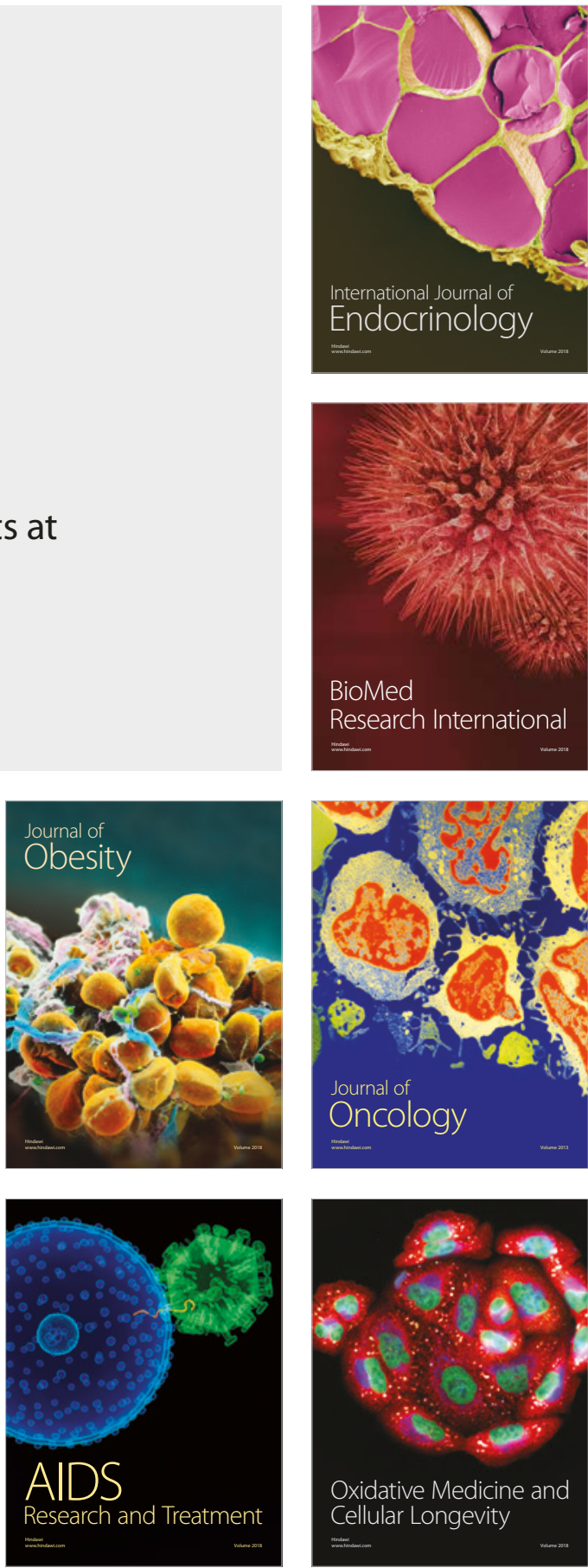